Review

\title{
Overview of Klebsiella Pneumoniae as a Nosocomial Pathogen and ESBL Producing Strains in Iran
}

\author{
${ }^{1}$ Fariba Akrami, ${ }^{2}$ Amirmorteza Ebrahimzadeh Namvar and ${ }^{3}$ Iman Vazife Sirzari \\ ${ }^{1,2}$ Department of Microbiology, Faculty of Medicine, Babol University of Medical Sciences, Babol, IR Iran, \\ ${ }^{3}$ Department of Management, Faculty of Mamegement, Ferdowsi University of Mashhad, Mashhad IR Iran
}

\author{
Article history \\ Received: 04-01-2019 \\ Revised: 23-02-2019 \\ Accepted: 09-03-2019 \\ Corresponding Author: \\ Fariba Akrami \\ Department of Microbiology, \\ Faculty of Medicine, Babol \\ University of Medical Sciences, \\ Babol, IR Iran, \\ Email: Fariba4820@gmail.com
}

\begin{abstract}
Klebsiella pneumoniae is one of the most important human bacterial pathogens with an extensive range of community and hospital acquired infections that may lead to morbidity and mortality. Evaluating the prevalence and epidemic sources of infections and the pathogenicity mechanism of bacteria can be investigated by various typing methods. The emergence of multi-drug resistant strains and extended-spectrum ß-lactamase (ESBL) producing isolates has already become a great challenge in nosocomial infection incidence. There are several reports on ESBL isolates of $K$. pneumoniae in Iran. However, our aim is a comprehensive analysis on ESBL isolates $K$. pneumoniae from different parts of Iran which has not yet been performed.
\end{abstract}

Keywords: Klebsiella Pneumonia, Nosocomial, Infection, ESBL

\section{Introduction}

Klebsiella pneumoniae is one of the most abundant species of the Klebsiella genus that causes complications such as urinary tract infections, Ventilator-Associated Pneumonia (VAP), sepsis and endophthalmitis in Asia and America. Emergence of multi-drug resistant strains has already become a great challenge in nosocomial infection incidence (Pokra et al., 2016; Kashani and Eliott, 2013). In 1883, Friedlander, the German microbiologist and pathologist, isolated the encapsulated bacilli from a patient with pneumonia. The bacterium was initially called Friedlander's bacillus but was renamed Klebsiella due to Edwin Klebs. Currently, the Klebsiella genus is classified among the five predominant common gram negative pathogens that could lead to nosocomial infections (Horan et al., 1988). Klebsiella oxytoca, Klebsiella rhinoscleromatis and Klebsiella ozaenae are the main subspecies of $K$. pneumoniae based on nucleic acid hybridization (Sakazaki et al., 1989). In addition, Klebsiella terrigena, Klebsiella ornithinolytica, Klebsiella planticola and Klebsiella aerogenes are known other species (Izard et al., 1981; Gavini et al., 1986; Iyer et al., 2017). Nowadays, more than $50 \%$ of these strains are isolated from wound, respiratory and urinary tract infections (Podschun and Ullmann, 1994). There are several reports on ESBL isolates of $K$. pneumoniae in Iran. However, a comprehensive analysis of ESBL isolates of $K$. pneumoniae from different parts of Iran has not yet been performed. The searches were done according to several English and Persian databases including PubMed, Scopus, Isi, Iranmedex and SID to identify studies addressing ESBL isolates of $K$. pneumoniae in Iran during the past decade.

\section{Genomic Structure}

In Holt and colleagues' study, more than 300 isolates of Klebsiella pneumoniae strains were investigated based on whole-genome sequencing method that lead to KpI (K. pneumoniae), KpII (K. quasipneumoniae) and KpIII $(\mathrm{K}$. variicola) as the three main distinct species, of which $K$. pneumoniae is the most significant one in human infections (Fig. 1). The most important gene clusters are associated with various virulence factors, regulators of mucoid phenotype (rmpA, rmpA2), siderophore systems, the ferric uptake operon $k f u A B C$, the two-component regulator $k v g A S$ and an allantoinase gene cluster. The three chromosomal core genes are classified as LEN $\beta$ lactamases, SHV and OKP. On the other hand both FosA and $o q x A B$ that associate in resistance to fosfomycin and quinolones have been transferred horizontally from Escherichia coli (Holt et al., 2015; Chen et al., 2014).

\section{Cell Structure, Metabolism and Natural Habitat}

The most vital metabolic pathways of $K$. pneumoniae are recapitulated as glycolysis, tricarboxylic acid, oxidation of fatty acids and creatine phosphate (Dong et al., 2012). Moreover $K$. pneumoniae is able to produce 2-butanone from glucose in 2-3 butanediol synthesis process (Chen et al., 2015). 


\section{A}

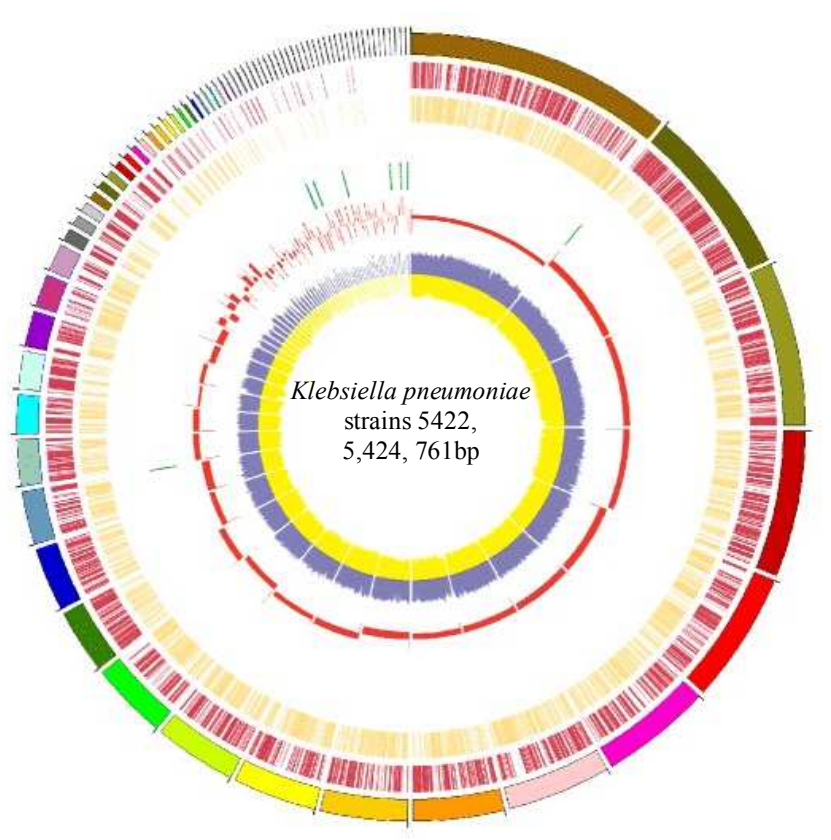

B

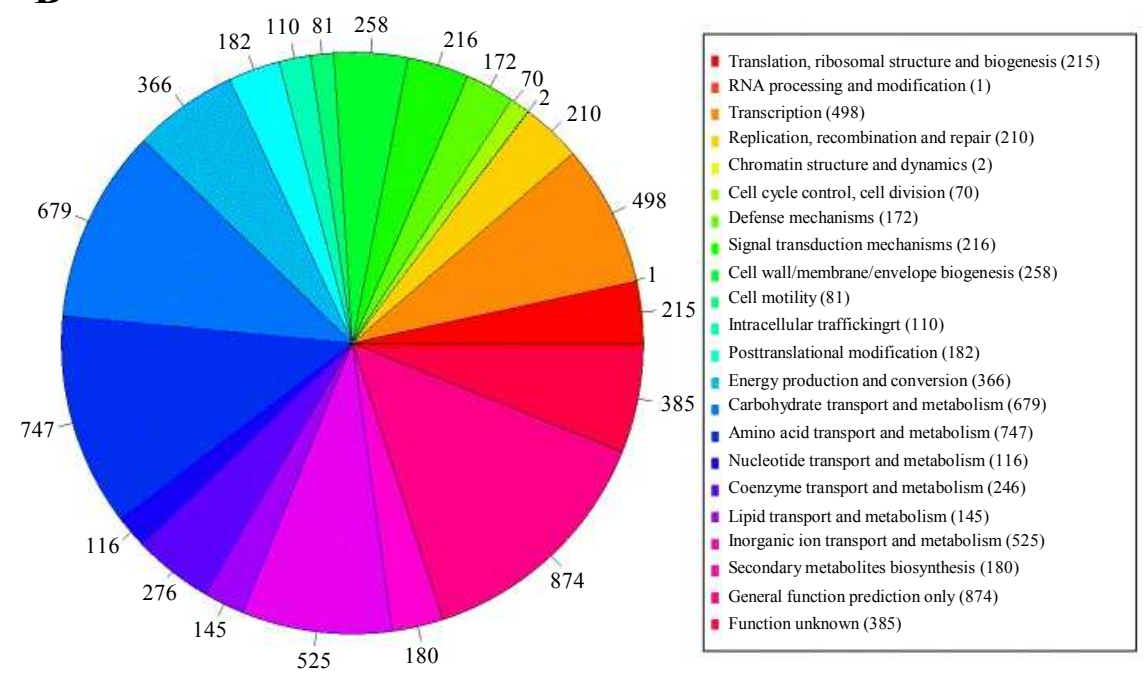

Fig. 1: The examples of $K$. pneumoniae sequencing strains (Zheng et al., 2014)

K. pneumoniae isolates from different sources such as environmental specimens, wastewater, soil, plants and mammalian mucosa, can also be found in the intestinal tract, nasopharynx and membrane surfaces as a saprophytic pathogen. It should be noted that indiscriminate antibiotic treatment is leading to the emergence of multidrug resistant strains (Tullus et al., 1988).

\section{Microbiology and Epidemiology}

$K$. pneumoniae belonging to the family Enterobacteriaceae is a Gram-negative, non-motile, encapsulated, lactose fermenting, facultative anaerobic, rod-shaped bacterium that can grow in potassium cyanide citrate with no growth at $10^{\circ} \mathrm{C}$ (Goetz et al., 1995). The main source of clinical infections is gastrointestinal tract infection and also hospital staff's hands, though the most outbreaks are found on neonatal wards (Montgomerie, 1979).

\section{Pathogenic Factors}

The most important virulence factors are as follows:

- Capsule: K. pneumoniae capsule structure which consists of repeating sugar units (4-6) which completely including uronic acid residues. This polysaccharide capsule has ability for attachment and producing biofilm formation, however, has 
enough capacity to provide resistance to desiccation, preserves from phagocytosis against polymorphonuclears and granulocytes and also from serum bactericidal effect and activation of the $\mathrm{C} 3 \mathrm{~b}$ complement (Magill et al., 2014; March et al., 2013). On the other hand, strains with repetitive sequences of mannose-a-2/3-mannose or 1rhamnose-a-2/3-1-rhamnose have less pathogenicity than others, until now 78 various capsular serotypes were defined (Hsu et al., 2013)

- Fimbriae: K. pneumonia has type 1 and 3 of pili, in which type 1 pili mediates hemagglutination of guinea pig erythrocytes, has the ability to interact with D-mannose residues of glycoprotein receptors on host cells and salivary and genital membrane surfaces (Gupta et al., 2003; Firon et al., 1984), whereas type 3 pili has capacity to mannoseresistant agglutination of human erythrocytes which were treated with tannic acid. This type of pilus consists of MrkA (original) and MrkD (adhesion) subunits that depends on mrkABCDF operon and responsible for biofilm formation, binding to tracheal epithelium, renal and lung tissue cells (Babu et al., 1986; Ares et al., 2017). Ares et al. conducted a study that confirms the essential role of H-NS protein in the regulation of type 3 polysaccharide capsule of $K$. pneumoniae (Ares et al., 2017)

- Outer Membrane Proteins (OMP): These proteins have a critical function in materials transport and pathogenicity. The role of OmpA as a eukaryotic cell adhesion, serum resistance and protects the bacteria against galectin-3 is noticeable (Ares et al., 2016). Moreover, OmpK35 and OmpK36 have been reported as a two main outer membrane porins, which are homologous as $\mathrm{OmpF}$ and OmpC. It should be mentioned that both OmpK35 and OmpK36 are related with Extended-spectrum Blactamase and associated with carbapenem resistance strains in $K$. pneumoniae respectively (Llobet et al., 2009; Tsai et al., 2011)

- Phospholipase activity: Lery et al. study indicates the role of phospholipase (Dpld1) as a new virulence factor in K. pneumoniae (Lery et al., 2014)

- Siderophore: these high-affinity iron-chelating compounds which were secreted by many microorganisms are required for bacterial growth, reproduction and spread of infection especially during pneumonia inflammation and bacterial dissemination. This event depends on the activation of the master transcription factor hypoxia inducible factor-1(HIF-1) protein and also inducing cytokine secretion (Holden et al., 2016)

\section{Typing Methods}

Evaluating the prevalence and epidemic sources of infections and the pathogenicity mechanism of bacteria can be investigated by various typing methods, like PFGE, MLST, RAPD, Rep-PCR and etc:

- Pulsed-field gel electrophoresis (PFGE): is one of the most common techniques for identifying the epidemiological and nosocomial source infections (Holden et al., 2016; de Souza Lopes et al., 2005)

- Multilocus Sequence Typing (MLST): This molecular technique has designed based on the study of DNA housekeeping genes and their alleles (Cuzon et al., 2010)

- RAPD: In this molecular technique the short random sequences of the bacterial genome are amplified by oligonucleotide primers (Holden et al., 2016)

- Rep-PCR: In this technique short repetitive sequences of bacteria are analyzed by oligonucleotide primers. This method is based on DNA fingerprinting techniques (Siu et al., 2011; Nielsen et al., 2011)

- MALDI-TOF Mass Spectrometry: matrix-assisted laser desorption/ionization- time-of-flight mass spectrometer is used for microbial identification, bacterial typing, epidemiological studies and also evaluation of antibiotic resistant strains (Perez et al., 2010)

- Conventional methods: serotyping, phage typing and bacteriocin typing are the most common methods and are used as the best typing for this bacteria (Berrazeg et al., 2013; Slopek et al., 1967; Rennie and Duncan, 1974)

\section{Antibiotic Resistance}

$K$. pneumoniae is naturally resistant against several antibiotic agents such as penicillin, ampicillin, amoxicillin, oxacillin, carbenicillin due to frequency of ß-lactamase genes (Ørskov and Ørskov, 1984; da Silva et al., 2012; Chambers, 2000). Resistance to ß-lactamase and carbapenem antibiotics is associated through a range of B-lactamase, such as strains SHV, TEM, CTX-M and carbapenemase respectively (Chaves et al., 2001). Strains which are harboring SHV-1 and TEM-1 may be resistant to piperacillin or first-generation cephalosporin (Grundmann et al., 2010; Girlich et al., 2000; Lemozy et al., 1995). Moreover, ESBL producing strains were reported for the first time in Germany that are responsible for resistance to cephalosporins such as cefotaxime, ceftriaxone and ceftazidime and monobactams (aztreonam) (Nicolas-Chanoine, 1997; Knothe et al., 1983). Due to this issue the prevalence of antibiotic-resistant A. baumannii strains have increased in Iran and this may cause significant clinical problems. In addition, the AmpC gene was also identified in $K$. pneumoniae strains, albeit in another form called MIR-1, which is $90 \%$ similar to Enterobacter cloacae. This gene contains FOX-1, FOX-2, FOX-3, CMY-2, CMY-4, CMY8, MOX-1, MOX-2, DHA-1, DHA-2, LAT-1, LAT-2 and 
ACC-1 (Jacoby and Sutton, 1991; Philippon et al., 2002). These strains are resistant to aminopenicillins, carboxypenicillins and ureidopenicillins, while these classes of genes are not well able to hydrolysis with cefepime or a carbapenem. Relevant studies that were performed in different region of Iran are described in Table 1.

\section{Treatment}

As shown in Table 1, reported Klebsiella resistance rates in Iran ranged as high as $96 \%$. and as seen in Fig. 2 , mean multidrug resistance rates generally increased over time and the last set of isolates collected in Iran were more resistant to all antibiotics $(30 \%)$. The highest rates of resistance were observed towards $\beta$-lactam antibiotics (ceftriaxone, cefotaxime, piperacillin, ceftazidime, cefepime, aztreonam and ampicillin). Also, most of the isolates from all over the country were still sensitive to imipenem, meropenem, tazocin, piperacillintazobactam and amikacin and the imipenem is still a effective drug in Iran.

\section{Prevention and Control}

According to conducted studies, identifying the risk factors and mechanisms of drug resistance is related to various enzymes that are produced, including ESBLs, MBLs, KPC and Amp-C belonging to Ambler A, B and $\mathrm{C}$ groups. Identification of these resistance factors will lead to the pivotal proper treatment. Direct contact limitation between patients and healthy people, following patients under treatment and compliance with individual health are the critical strategies for controlling the outbreak infections.

Table 1: The prevalence of antibiotic-resistant ESBL producing strains in the different regions of Iran

\begin{tabular}{|c|c|c|c|c|c|c|c|}
\hline Authors & $\begin{array}{l}\text { The percentage } \\
\text { of ESBL } \\
\text { producing strains }\end{array}$ & Genes & $\begin{array}{l}\text { The Highest rate of } \\
\text { antibiotic resistance }\end{array}$ & $\begin{array}{l}\text { enrollment } \\
\text { time }\end{array}$ & $\begin{array}{l}\text { Type of } \\
\text { sample }\end{array}$ & Province & References \\
\hline Shahcheraghi et al. (2007) & $33 \%$ & - & $\begin{array}{l}\text { Carbenicillin, Piperacilin, } \\
\text { Cefotaxime and Ceftriaxone }\end{array}$ & 2006 & $\begin{array}{l}\text { urine, blood, wounds, } \\
\text { sputum, CSF, central } \\
\text { venous line and } \\
\text { intra-abdominal abscess }\end{array}$ & Tehran & (Shahcheraghi et al 2007) \\
\hline Aminzadeh et al. (2008) & $52.5 \%$ & - & $\begin{array}{l}\text { Ampicillin, Cephalothin, } \\
\text { and Ceftazidime }\end{array}$ & 2007 & urine & Tehran & (Aminzadeh et al., 2008) \\
\hline Behrooozi et al. (2010) & $12 \%$ & - & $\begin{array}{l}\text { Cefazolin, Cephalothin, } \\
\text { Ceftazidime, Ampicillin, } \\
\text { Carbenicillin and Ceftizoxime }\end{array}$ & 2009 & urine & Tehran & (Behrooozi et al., 2010) \\
\hline Nasehi et al. (2010) & $96 \%$ & $\begin{array}{l}\text { blaSHV }(26 \%), \\
\text { blaTEM }(18 \%), \\
\text { blaPER }(7.5 \%)\end{array}$ & $\begin{array}{l}\text { Ceftazidime, Cefotaxime, } \\
\text { and Piperacilin }\end{array}$ & 2006-2007 & $\begin{array}{l}\text { urine, blood, wound, } \\
\text { sputum, CSF, central } \\
\text { venous line, intra } \\
\text { abdominal abscess, } \\
\text { throat, sperm, stool, vaginal } \\
\text { swab, trachea, dialysate solution }\end{array}$ & $\begin{array}{l}\text { from different } \\
\text { three general and } \\
\text { two private } \\
\text { hospitals in Iran }\end{array}$ & (Nasehi et al., 2010) \\
\hline Mansouri et al. (2012) & $41.3 \%$ & $\begin{array}{l}\text { blaCTX-M }(20 \%) \\
\text { blaCMY }(2.6 \%)\end{array}$ & $\begin{array}{l}\text { Amoxicillin, Cephalexin, } \\
\text { Ceftazidime and Gentamicin }\end{array}$ & 2007-2008 & $\begin{array}{l}\text { urine, blood } \\
\text { and other body }\end{array}$ & kerman & (Mansouri et al., 2012) \\
\hline Eftekhar et al. (2012) & $27.45 \%$ & $\begin{array}{l}\text { blaSHV }(43.14 \%), \\
\text { blaCTX-M }(13.37 \%), \\
\text { blaTEM }(35.29 \%)\end{array}$ & $\begin{array}{l}\text { Amoxicillin, Nitrofurantoin } \\
\text { and Ciprofloxacin }\end{array}$ & 2008 & Urine & Tehran & (Eftekhar et al., 2012) \\
\hline Riyahi Zaniani et al. (2012) & $20 \%$ & $\begin{array}{l}\operatorname{blaTEM}(8.77 \%), \\
\operatorname{blaSHV}(10.52 \%)\end{array}$ & - & 2009-2010 & $\begin{array}{l}\text { out-patients and hospitalized } \\
\text { patients from urine, blood, } \\
\text { wound and abscess aspirates, } \\
\text { peritonitis and pulmonary } \\
\text { secretions }\end{array}$ & Mashhad & (Riyahi Zaniani et al., 2012) \\
\hline Khosravi et al. (2013) & $47.27 \%$ & $\begin{array}{l}\text { BlaSHV-1(46.15\%) } \\
\text { blaTEM- }-(43.165 \%), \\
\text { blaCTX-M-1(26.92\%) }\end{array}$ & $\begin{array}{l}\text { Amoxicillin/clavulanic Acid, } \\
\text { Amoxicillin, Ampicillin, } \\
\text { and Cefoxitin }\end{array}$ & 2012 & - & Ahvaz & (Khosravi et al., 2013) \\
\hline Azimi et al. (2014) & - & $\begin{array}{l}\text { BlaOXA-48(96.47\%), } \\
\text { blaVIM-4 }(3.57 \%)\end{array}$ & $\begin{array}{l}\text { Cephalosporins, Carbapenems } \\
\text { (imipenem, Ertapenem, } \\
\text { meropenem), Trimethoprim- } \\
\text { sulfamethoxazole and Quinolones }\end{array}$ & 2011 & from patients a burn unit & Teheran & (Azimi et al., 2014) \\
\hline Derakhshan et al. (2014) & $54.9 \%$ & blaCTX-M $(54.9 \%)$ & Cefotaxime & 2011 & $\begin{array}{l}\text { urine, wound, tracheal } \\
\text { secretions and other } \\
\text { samples (including catheter, } \\
\text { eye and etc.). }\end{array}$ & Teheran & (Derakhshan et al., 2014) \\
\hline Hashemi et al. (2014) & $57.5 \%$ & $\begin{array}{l}\text { blaKPC }(6 \%), \\
\text { blaCTX-M-15 } \\
(62.5 \%) \\
\text { blaOXA-48 }(4.1 \%)\end{array}$ & $\begin{array}{l}\text { Ampicillin, Cefpodoxime, } \\
\text { Cefotaxime and Piperacillin }\end{array}$ & 2012 & $\begin{array}{l}\text { urine, blood culture, wound, } \\
\text { sputum, intra-abdominal, } \\
\text { cerebrospinal fluid, } \\
\text { and other samples }\end{array}$ & Tehran & (Hashemi et al.. 2014) \\
\hline Gholipour et al. (2014) & $38.18 \%$ & blaSHV (14.28) & $\begin{array}{l}\text { Cefotaxime, Ampicillin, } \\
\text { Ceftazidime and Ciprofloxacin }\end{array}$ & 2012 & urinary tract infections & Isfahan & (Gholipour et al., 2014) \\
\hline Raei et al. (2014) & $46.9 \%$ & & $\begin{array}{l}\text { Ceftriaxone, Cefotaxime, } \\
\text { Piperacillin and Aztreonam }\end{array}$ & 2008-2012 & - & Tehran & (Raei et al., 2014) \\
\hline Mansouri et al. (2014) & $28 \%$ & - & $\begin{array}{l}\text { Amoxicillin, Cephalexin, } \\
\text { Ceftazidime and Gentamicin }\end{array}$ & 2007-2008 & blood, urine and body fluids & Kerman & (Mansouri et al., 2014) \\
\hline Izadi et al. (2014) & $43 \%$ & $\begin{array}{l}\text { blaTEM }(87.54 \%) \\
\text { blaSHV }(69.64 \%)\end{array}$ & $\begin{array}{l}\text { Gentamicin, } \\
\text { Trimethoprim-sulfamethoxazol } \\
\text { and Meropenem }\end{array}$ & 2011-2012 & urine, wound, blood & Mashhad & (Izadi et al., 2014) \\
\hline Saeidi et al. (2014) & $66.6 \%$ & $\begin{array}{l}\operatorname{blaCTX}-M(65 \%) \\
\operatorname{blaTEM}(65 \%)\end{array}$ & $\begin{array}{l}\text { Ceftazidime, Ampicillin, } \\
\text { Gentamicin and }\end{array}$ & 2010- 2011 & urine culture & Zabol & (Saeidi et al., 2014) \\
\hline Fazeli et al. (2015) & - & blaNDM-1 (12.2\%) & $\begin{array}{l}\text { Piperacillin, aztreonam, } \\
\text { and ceftazidime }\end{array}$ & 2012- 2013 & $\begin{array}{l}\text { urine, tracheal aspirate, } \\
\text { bronchoalveolar-lavage (BAL) } \\
\text { fluid, wound, abscess, } \\
\text { cerebrospinal fluid, sputum, } \\
\text { catheter and eye }\end{array}$ & Isfahan & (Fazeli et al, 2015) \\
\hline Rajabnia et al. (2015) & $30 \%$ & blaVIM-1 $(30 \%)$ & Imipenem & 2015 & patients at ICU & Babol & (Rajabnia et al., 2015) \\
\hline Mansury et al. (2016) & $26.3 \%$ & $\begin{array}{l}\text { blaSHV }(22.2 \%), \\
\text { blaCTX-M }(19 \%), \\
\text { blaTEM }(16 \%)\end{array}$ & $\begin{array}{l}\text { Amoxicillin, } \\
\text { Trimethoprim-sulfamethoxazol, } \\
\text { and Cefpodoxime }\end{array}$ & 2012-2013 & $\begin{array}{l}\text { from urine, sputum, } \\
\text { wound, body fluids, blood, } \\
\text { throat and other samples }\end{array}$ & Shiraz & (Mansury et al., 2016) \\
\hline Maleki et al. (2018) & $25.5 \%$ & $\begin{array}{l}\text { blaCTX-M }(92 \%) \\
\text { and blaTEM }(76 \%)\end{array}$ & $\begin{array}{l}\text { Cefotaxime } \\
\text { and Ceftazidime }\end{array}$ & 2013 & urine & Isfahan & (Maleki et al., 2018) \\
\hline
\end{tabular}




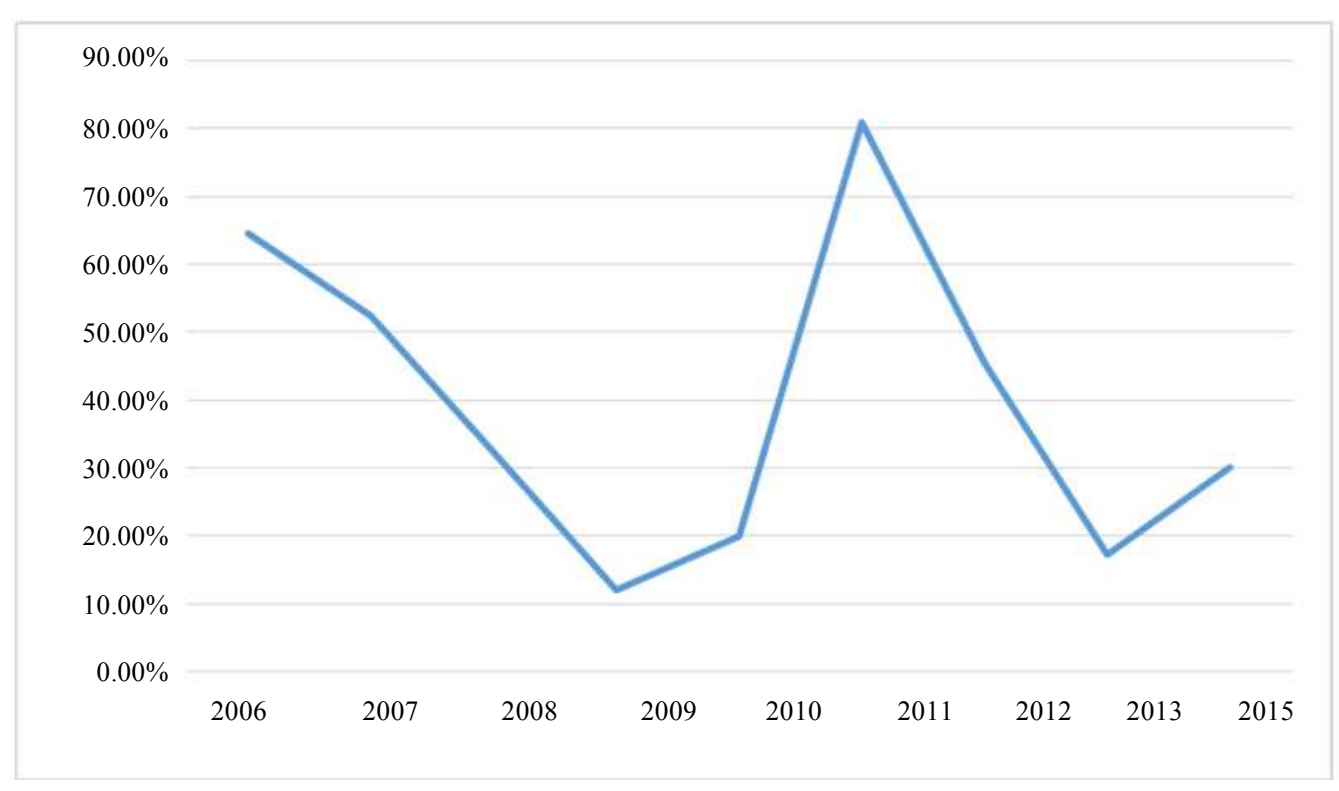

Fig. 2: Percentage of ESBL strains over time in Iran

Loss of this porin may be one of the factors contributing to antimicrobial resistance among ESBL-producing $K$. pneumoniae and may favor the selection of additional mechanisms of resistance. Microbiology laboratories must be able to identify resistant bacteria in a timely suitable manner, especially those that are falsely susceptible in vitro to antibiotics. Bacteriological excellence is needed more than ever (57).

\section{Conclusion}

There is a relatively high prevalence of drug resistant $K$. pneumoniae isolates in Iran. This review showed that the prevalence of ESBL-producing $K$. pneumoniae varies in different regions of Iran and the capital city of Iran (Tehran,) has a higher incidence of ESBL compared to northern regions and the western cities. Thus, a high degree of awareness among physicians and microbiologists, active infection control committees, appropriate antimicrobial therapy, improvement of hygiene conditions and monitoring of drug resistant isolates are urgently needed in order to better control the emergence and spread of ESBL $K$. pneumonia isolates in hospital settings.

\section{Ethical Consideration}

Ethical issues (Including plagiarism, informed consent, misconduct, data fabrication and/or falsification, double publication and/or submission, redundancy, etc.) have been completely addressed by the authors.

\section{Conflict of Interests}

The authors declare that there is no conflict of interests.

\section{References}

Aminzadeh, Z., M. Sadat Kashi and M. Shabani, 2008. Bacteriuria by Extended-Spectrum Beta-LactamaseProducing Escherichia Coli and Klebsiella Pneumoniae Isolates in a Governmental Hospital in south of Tehran, Iran. Iran J. Kidney Dis., 2: 197-200.

Ares, M.A., J.L. Fernández-Vázquez, R. Rosales-Reyes, M.D. Jarillo-Quijada and K. von Bargen et al., 2016. H-NS Nucleoid Protein Controls Virulence Features of Klebsiella pneumoniae by regulating the Expression of Type 3 Pili and the Capsule Polysaccharide, 6: 13.

Ares, M.A., J.L. Fernández-Vázquez, S. Pacheco, V.I. Martínez-Santos and M.D. Jarillo-Quijada et al., 2017. Additional regulatory activities of MrkH for the transcriptional expression of the Klebsiella pneumoniae mrk genes: Antagonist of H-NS and repressor. PLoS One, 9): e0173285.

Azimi, L., P. Nordmann, A. Rastegar Lari and R. Bonnin, 2014. First report of OXA-48-producing Klebsiella pneumonia strains in Iran. GMS Hygiene Infec. Control.

Babu, J.P., S.N. Abraham, M.K. Dabbous and E.H. Beachey, 1986. Interaction of a 60-Kilodalton Dmannose-containing salivary glycoprotein with type 1 fimbriae of Escherichia coli. Infect. Immun., 54: 104-108.

Behrooozi, A., M.V. Rahbar and J. Yousefi, 2010. Frequency of extended spectrum beta-lactamase (ESBLs) producing Escherichia coli and klebseilla pneumonia isolated from urine in an Iranian 1000-bed tertiary care hospital. Afr. J. Microbiol. Res., 4: 881-884. 
Berrazeg, M., S.M. Diene, M. Drissi, M. Kempf and H. Richet et al., 2013. Biotyping of multidrug-resistant Klebsiella pneumoniae clinical isolates from France and Algeria Using MALDI-TOF MS. PLoS One, 19: e61428.

Chambers, H.F., 2000. Penicillins. In: Principles and Practice of Infectious Diseases, Mandell, G.L., J.E. Bennett and R. Dolin (Eds.), Churchill Livingstone, New York.

Chaves, J., M.G. Ladona, C. Segura, A. Coira and R. Reig et al., 2001. SHV-1 beta-lactamase is mainly a chromosomally encoded species-specific enzyme in Klebsiella pneumoniae. Antimicrob Agents Chemother, 45: 2856-2861.

Chen, L., B. Mathema, K. Chavda, F. DeLeo and R. Bonomo et al., 2014. Carbapenemase-producing Klebsiella pneumoniae: molecular and genetic decoding. Public Trends Microbiol., 22: 686-696.

Chen, Z., H. Sun, J. Huang, Y. Wu and D. Liu, 2015. Metabolic engineering of Klebsiella pneumoniae for the production of 2-butanone from glucose. PLoS One, 14: 10:e140508.

Cuzon, G., T. Naas, H. Truong, M.V. Villegas and K.T. Wisell et al., 2010. Worldwide Diversity of Klebsiella pneumoniae That Produce $\beta$-Lactamase blaKPC-2 Gene. Emerg. Infect. Dis., 16: 1349-56.

da Silva, R.M., J. Traebert and D. Galato, 2012. Klebsiella pneumonia carbapenemase (KPC)producing Klebsiella pneumoniae: A review of epidemiological and clinical aspects. Expert. Opin. Biol. Ther., 12: 663-71.

de Souza Lopes, A.C., J. Falcão Rodrigues, M.A. de Morais Júnior, 2005. Molecular typing of Klebsiella pneumoniae isolates from public hospitals in Recife, Brazil. Microbiol. Res., 160: 37-46.

Derakhshan, S., S. Najar Peerayeh, F. Fallah, B. Bakhshi and M. Rahbar et al., 2014. Detection of Class 1, 2 and 3 Integrons among Klebsiella pneumoniae isolated from children in Tehran Hospitals. Arch Pediatr Infect. Dis.

Dong, F., B. Wang, L. Zhang, H. Tang and J. Li et al., 2012. Metabolic Response to Klebsiella pneumoniae Infection in an Experimental Rat Model. PLoS One, 7: e51060.

Eftekhar, F., M. Rastegar, M. Golalipoor and N. Mansouri Samae, 2012. Detection of extended spectrum B-lactamases in urinary isolates of Klebsiella pneumoniae in Relation to BlaSHV, BlaTEM and BlaCTX-M Gene Carriage. Iranian J. Publ. Health, 41: 127-132.

Fazeli, H., M. Norouzi-Barough, A.M. Ahadi, D. Shokri and H. Solgi, 2015. Detection of New Delhi Metallo-Beta-Lactamase-1 (NDM-1) in carbapenem resistant Klebsiella pneumoniae isolated from a university hospital in Iran. HIPPOKRATIA, 19: 205-209.
Firon, N., I. Ofek and N. Sharon, 1984. Carbohydratebinding sites of the mannose-specific fimbria llectins of enterobacteria. Infect. Immun., 43: 1088-1090.

Gavini, F., D. Izard, P. Grimon, A. Beji and E. Ageron et al., 1986. Priority of Klebsiella planticola Bagley, Seidler and Brenner 1982 over Klebsiella trevisanii Ferragut, Izard, Gavini, Kersters, DeLey and Leclerc 1983. Int. J. Syst. Bacteriol., 36: 486-488.

Gholipour, A., N. Soleimani, D. Shokri, S. Mobasherizadeh and M. Kardi et al., 2014. Phenotypic and molecular characterization of extended-spectrum $\beta$-Lactamase produced by Escherichia coli and Klebsiella pneumoniae Isolates in an educational Hospital. Jundishapur J. Microbiol., 7: e11758.

Girlich, D., A. Karim, L. Poirel, M.H. Cavin and C. Verny et al., 2000. Molecular epidemiology of an outbreak due to IRT-2 beta-lactamase producing strains of Klebsiella pneumoniae in a geriatric department. J. Antimicrob. Chemother, 45: 467-473.

Goetz, A.M., J.D. Rihs, J.W. Chow, N. Singh and R.R. Muder, 1995. An outbreak of infusion-related Klebsiella pneumoniae bacteremia in a liver transplantation unit. Clin Infect. Dis., 21: 1501-1503.

Grundmann, H., D.M. Livermore, C.G. Giske, R. Canton and G.M. Rossolini et al., 2010. CNSE Working Group. Non-susceptible Enterobacteriaceae in Europe: conclusions from a meeting of national experts. Eur. Surveill., 18: pii: 19711.

Gupta, A., K. Ampofo, D. Rubenstein and L. Saiman, 2003. Extended Spectrum b Lactamase-producing Klebsiella pneumoniae Infections: A Review of the Literature. J. Perinatol., 23: 439-43.

Hashemi, A., F. Fallah, S. Erfanimanesh, P. Hamedani and S. Alimehr et al., 2014. Detection of $\beta$-Lactamases and Outer Membrane Porins among Klebsiella pneumoniae Strains Isolated in Iran. Scientifica.

Holden, V.I., P. Breen, S. Houle, C.M. Dozois and M.A. Bachman, 2016. Klebsiella pneumoniae Siderophores Induce Inflammation, Bacterial Dissemination and HIF-1 $\alpha$ Stabilization during Pneumonia. MBio., 3: 7.pii: e01397-16.

Holt, K., H. Wertheim, R. Zadoks, S. Baker and C. Whitehouse et al., 2015. Genomic analysis of diversity, population structure, virulence and antimicrobial resistance in Klebsiella pneumoniae, an urgent threat to public health. PNAS.

Horan, T., D. Culver, W. Jarvis, G. Emori and S. Banerjee et al., 1988. Pathogens causing nosocomial infections. Antimicrob Newslett., 5: 65-67.

Hsu, C.R., T.L. Lin, Y.J. Pan, P.F. Hsieh and J.T. Wang, 2013. Isolation of a bacteriophage specific for a new capsular type of Klebsiella pneumoniae and characterization of its polysaccharide depolymerase. PLoS One, 2: 8:e70092. 
Iyer, R., B. Iken and A. Damania, 2017. Whole genome of Klebsiella aerogenes PX01 isolated from San Jacinto River sediment west of Baytown, Texas reveals the presence of multiple antibiotic resistance determinants and mobile genetic elements. Genom Data, 14: 7-9.

Izadi, N., M. Naderi Nasab, E. Harifi Mood and Z. Meshkat, 2014. Prevalence of TEM and SHV Genes in Clinical isolates of Klebsiella pneumonia From Mashhad, North- East Iran. Iran J. Pathol., 9: 199-205.

Izard, D., C. Ferragut, F. Gavini, K. Kersters and J. De Ley et al., 1981. Klebsiella terrigena, a new species from soil and water. Int. J. Syst. Bacteriol., 31: 116-127.

Jacoby, G.A. and L. Sutton, 1991. Properties of plasmids responsible for production of extended-spectrum beta- lactamases. Antimicrob Agents Chemother, 35: 164-169.

Kashani, A.H. and D. Eliott, 2013. The emergence of Klebsiella pneumoniae endogenous endophthalmitis in the USA: Basic and clinical advances. J. Ophthalmic Inflamm Infect., 3: 28.

Khosravi, A., H. Hoveizavi and M. Mehdinejad, 2013. Prevalence of Klebsiella pneumoniae Encoding Genes for CTX-M-1, TEM-1and SHV-1 Extended-Spectrum Beta Lactamases (ESBL) Enzymes in Clinical Specimens. Jundishapur J. Microbiol., 6: e8256.

Knothe, H., P. Shah, V. Krcmery, M. Antal and S. Mitsuhashi, 1983. Transferable resistance to cefotaxime, cefoxitin, cefamandole and cefuroxime in clinical isolates of Klebsiella pneumoniae and Serratia marcescens. Infection, 11: 315-317.

Lemozy, J., D. Sirot, C. Chanal, C. Huc and R. Labia et al., 1995. First characterization of inhibitorresistant TEM (IRT) beta-lactamases in Klebsiella pneumoniae strains. Antimicrob Agents Chemother., 39: 2580-2582.

Lery, L.M., L. Frangeul, A. Tomas, V. Passet and A.S. Almeida et al., 2014. Comparative analysis of Klebsiella pneumoniae genomes identifies a phospholipase D family protein as a novel virulence factor. BMC Biol., 29: 12-41.

Llobet, E., C. March, P. Giménez and J.A. Bengoechea, 2009. Klebsiella pneumoniae OmpA Confers Resistance to Antimicrobial. Agents Chemother, 53: 298-302.

Magill, S.S., J.R. Edwards, W. Bamberg, Z.G. Beldavs and G. Dumyati et al., 2014. Emerging infections program healthcare-associated infections and antimicrobial use prevalence survey team: Multistate point-prevalence survey of health care-associated infections. N Engl. J. Med., 370: 1198-1208.
Maleki, N., Z. Tahanasab, S. Mobasherizadeh, A. Rezaei and J. Faghri, 2018. Prevalence of CTX-M and TEM- $\beta$-lactamases in Klebsiella pneumoniaeIsolates from Patients with Urinary Tract Infection, Al-Zahra Hospital, Isfahan, Iran. Adv. Biomed. Res., 7: 10.

Mansouri, S., D. Kalantar, P. Asadollahi, M. Taherikalani and M. Emaneini et al., 2012. Characterization of Klebsiella pneumoniae strains producing extended spectrum beta-lactamases and AMPC type beta-lactamases isolated from hospitalized patients in Kerman, Iran. Roum. Arch Microbiol. Immunol., 71: 81-86.

Mansouri, S., D. KalantarNeyestanaki, M. Shokoohi, S. Halimi and R. Beigverdi et al., 2014. Characterization of AmpC, CTX-M and MBLs types of $\beta$-lactamases in clinical isolates of Klebsiellapneumoniaeand Escherichia coli producing Ex $\neg$ tended Spectrum $\beta$-lactamases in Kerman, Iran. Jundishapur J. Microbiol., 7: e8756.

Mansury, D., M. Motamedifar, J. Sarvari, B. Shirazi and A. Khaledi, 2016. Antibiotic susceptibility pattern and identification of extended spectrum $\beta$-lactamases (ESBLs) in clinical isolates of Klebsiella pneumoniae from Shiraz, Iran. IJMV. 8: 55-61.

March, C., V. Cano, D. Moranta, E. Llobet and C. PérezGutiérrez et al., 2013. Role of bacterial surface structures on the interaction of Klebsiella pneumoniae with phagocytes. PLoS One, 8: e56847.

Montgomerie, J.Z., 1979. Epidemiology of Klebsiella and hospital-associated infections. Rev. Infect. Dis., 1: 736-753.

Nasehi, L, F. Shahcheraghi, V. Nikbin and S. Nematzadeh, 2010. PER, CTX-M, TEM and SHV Beta-lactamases in Clinical Isolates of Klebsiella pneumoniae Isolated from Tehran, Iran. IJBMS. 3: 111-118.

Nicolas-Chanoine, M.H., 1997. Inhibitor-resistant betalactamases. J. Antimicrob Chemother, 40: 1-3.

Nielsen, J.B., M.N. Skov, R.L. Jørgensen, O. Heltberg and D.S. Hansen et al., 2011. Identification of CTXM15-, SHV-28-producing Klebsiella pneumoniae ST15 as an epidemic clone in the Copenhagen area using a semi-automated Rep-PCR typing assay. Eur. J. Clin. Microbiol. Infect. Dis., 30: 773-8.

Ørskov, I. and F. Ørskov, 1984. Serotyping of Klebsiella. Methods Microbiol., 14: 143-164.

Perez, F., A. Endimiani, A.J. Ray, B.K. Decker and C.J. Wallace et al., 2010. Carbapenem-resistant Acinetobacter baumannii and Klebsiella pneumoniae across a hospital system: impact of post-acute care facilities on dissemination. J. Antimicrob. Chemother, 65: 1807-18.

Philippon, A., G. Arlet and G.A. Jacoby, 2002. Plasmiddetermined AmpC-type beta-lactamases. Antimicrob Agents Chemother, 46: 1-11.

Podschun, R. and U. Ullmann, 1994. Incidence of Klebsiella planticola among clinical Klebsiella isolates. Med. Microbiol Lett., 3: 90-95. 
Pokra, M., D.K. Sharma, P. Mehta, H.R. Verma and S. Pundir et al., 2016. Its Alarming, Klebsiella spp. Towards Multidrug Resistance. Int. J. Curr. Microbiol. App. Sci., 5: 150-160.

Raei, F., F. Eftekhar and M. Feizabadi, 2014. Prevalence of quinolone resistance among extended-Spectrum $\beta$ -lactamase producing uropathogenic Klebsiella pneumonia. Jundishapur J. Microbiol., 7: e10887.

Rajabnia, R., F. Asgharpour, E. FerdosiShahandashti and Z. Moulana, 2015. Nosocomial emerging of (VIM1) carbapenemase-producing isolates of Klebsiella pneumoniae in North of Iran. IJMV, 7: 88-93.

Rennie, R.P. and I.B. Duncan, 1974. Combined biochemical and serological typing of clinical isolates of Klebsiella. Appl. Microbiol., 28: 534-539.

Riyahi Zaniani, F., Z. Meshkat, M. Naderi Nasab, M. Khaje-Karamadini and K. Ghazvini et al., 2012. The Prevalence of TEM and SHV genes among extended-spectrum beta-lactamases producing Escherichia Coli and Klebsiella Pneumoniae. Iran J. Basic. Med. Sci., 15: 654-660. 23493850

Saeidi, S., R. Alavi-Naini and S. Shayan, 2014. Antimicrobial susceptibility and distribution of TEM and CTX-M Genes among ESBL-producing Klebsiella pneumoniae and Pseudomonas aeruginosa Causing Urinary Tract Infections. Zahedan J. Res. Med. Sci., 16: 1-5.

Sakazaki, R., K. Tamura, Y. Kosako and E. Yoshizaki, 1989. Klebsiella ornithinolytica sp. nov., formerly known as ornithine-positive Klebsiellaoxytoca. Curr. Microbiol., 18: 201-206.
Shahcheraghi, F., H. Moezi and M. Mehdi Feizabad, 2007. Distribution of TEM and SHV b-lactamase genes among Klebsiella pneumoniae strains isolated from patients in Tehran. Med. Sci. Monit., 13: BR247-250.

Siu, LK., C.P. Fung, F.Y. Chang, N. Lee and K.M. Yeh et al., 2011. Molecular typing and virulence analysis of serotype K1 Klebsiella pneumoniae strains isolated from liver abscess patients and stool samples from noninfectious subjects in Hong Kong, Singapore and Taiwan. J. Clin. Microbiol., 49: 3761-5.

Slopek, S., A. Przondo-Hessek, H. Milch and S. Deák, 1967. A working scheme for bacteriophage typing of Klebsiella bacilli. Arch. Immunol. Ther. Exp. (Warsz), 15: 589-99.

Tsai, Y.K., C.P. Fung, J.C. Lin, J.H. Chen and F.Y. Chang et al., 2011. Klebsiella pneumoniae Outer Membrane Porins OmpK35 and OmpK36 Play Roles in both Antimicrobial Resistance and Virulence. Antimicrob Agents Chemother, 55: 1485-93.

Tullus, K., B. Berglund, B. Fryklund, I. Ku“hn and L.G. Burman, 1988. Epidemiology of fecal strains of the family Enterobacteriaceae in 22 neonatal wards and influence of antibiotic policy. J. Clin. Microbiol. 26: 1166-1170.

Zheng, B., A. Li, X. Jiang, X. Hu and J. Yao et al., 2014. Genome sequencing and genomic characterization of a tigecycline-resistant Klebsiella pneumoniae strain isolated from the bile samples of a cholangiocarcinoma patient. Gut Pathog., 27: 6-40. 